\title{
Instrukcja dla Głównego Więzienia Inkwizycyjnego w Warszawie z 26 listopada/8 grudnia 1835 r. i uwagi do niej Nadzorcy Głównego Więzienia Karnego w Warszawie z 11/23 czerwca 1858 r.
}

\section{WSTĘP}

Środek zapobiegawczy w postaci tymczasowego aresztowania znany był już $\mathrm{w}$ dawnym prawie polskim ${ }^{1}$. Przez cały okres istnienia I Rzeczypospolitej brakowało jednak regulacji dotyczących zasad stosowania tego środka, uprawnionych podmiotów czy dopuszczalnego czasu pozbawienia wolności bez wyroku sądowego. Podobnie do rzadkości należały odrębne miejsca służące do przetrzymywania osób tymczasowo aresztowanych. Na ten cel zazwyczaj wykorzystywano instytucje penitencjarne przeznaczone do odbywania kary pozbawienia wolności ${ }^{2}$, gdzie aresztantów zazwyczaj przetrzymywano w fatalnych warunkach w jednych pomieszczeniach ze skazanymi.

Dopiero w drugiej połowie XVIII w. pojawiają się koncepcje zasad wykonywania tymczasowego aresztowania, $w$ tym postulat rozdziału osób aresztowanych od już skazanych. Poglądy takie znalazły się choćby w projekcie Kodeksu Stanisława Augusta Poniatowskiego. Twórcy tego dzieła, Hugo Kołłątaj i Józef Szymanowski, podkreślali konieczność rozdzielenia więzień karnych od śledczych ${ }^{3}$. Ostatecznie

\footnotetext{
${ }^{1}$ L. Rabinowicz, Podstawy nauki o więziennictwie, Warszawa 1933, s. 4.

${ }^{2}$ Szerzej na temat wieży górnej: T. Adamczyk, O karze pozbawienia wolności w orzecznictwie krakowskiego sadu grodzkiego w XVIII wieku uwag kilka, „Z Dziejów Prawa” 2011, t. 4, s. 53-57; J. Makarewicz, Polskie prawo karne. Część ogólna, Lwów - Warszawa 1919, s. 263.

${ }^{3}$ M. Czerwiec, Więzienioznawstwo. Zarys rozwoju więziennictwa, Warszawa 1958, s. 48; E. Kaczyńska, Ludzie ukarani. Więzienia i system kar w Królestwie Polskim 1815-1914, Warszawa 1989, s. 26-27.
} 
dopiero wiek XIX przyniósł rzeczywiste rozwiązania. W obowiązujących na ziemiach zaboru pruskiego i austriackiego procedurach karnych pojawiają się wówczas regulacje nakazujące organizację odrębnych ośrodków dla przetrzymywania osób tymczasowo aresztowanych.

Jednak w okresie Księstwa Warszawskiego nie udało się jeszcze w pełni przeprowadzić reform organizacji więziennictwa. Nie dokonano też podziału więzień dla skazanych i tymczasowo aresztowanych. Jak wskazuje Jerzy Czołgoszewski, taki podział istniał tylko w Warszawie ${ }^{4}$.

Dopiero czasy Królestwa Polskiego przyniosły praktyczne reformy organizacji więziennictwa, także w zakresie zasad wykonywania aresztu tymczasowego. Niemały wkład w to mieli polscy penitencjaryści pozostający pod wpływem europejskich prądów oświeceniowych, a zagadnienia dotyczące instytucji zatrzymania przed wyrokiem były istotną częścią prowadzonych ówcześnie dyskusji.

Jedną z głównych postaci był Fryderyk Skarbek. To dzięki jego działaniom w 1835 r. uruchomiono duże nowoczesne więzienie śledcze, między ul. Dzielną 24/26 a ul. Pawią w Warszawie, zwane potocznie Pawiakiem (choć oficjalnie nosiło następujące nazwy: Więzienie Główne Inkwizycyjne, Główny Dom Badań, wreszcie Warszawskie Więzienie Śledcze) $)^{5}$.

W niniejszym artykule zostaną przedstawione zasady funkcjonowania Głównego Więzienia Inkwizycyjnego na podstawie wydanej 26 listopada/8 grudnia $1835 \mathrm{r}$. instrukcji oraz uwagi do niej przedstawione w odnalezionym przez autorkę w Archiwum Głównym Akt Dawnych w Warszawie dokumencie z 11/23 czerwca $1858 \mathrm{r}$. W piśmie tym Nadzorca Głównego Więzienia Karnego w Warszawie, wykonując zobowiązanie Rządu Gubernialnego Warszawskiego, na kanwie dotychczasowych doświadczeń wskazuje zmiany, jakie w jego ocenie powinny zostać wprowadzone do tej instrukcji. Jest to o tyle istotne, że rzuca pewne światło na praktykę funkcjonowania i organizacji Głównego Więzienia Inkwizycyjnego, która nie zawsze znajdowała odzwierciedlenie w obowiązującej instrukcji.

\section{FRYDERYK SKARBEK JAKO POMYSŁODAWCA BUDOWY NOWEGO WIĘZIENIA ŚLEDCZEGO W WARSZAWIE}

Fryderyk Skarbek zapisał się w dziejach naszego kraju jako jeden najwybitniejszych penitencjarystów i głównych prekursorów reformy więziennictwa w pierwszej połowie XIX w. W 1828 r. będąc członkiem Komisji Rządowej Sprawiedliwości, z polecenia ministra spraw wewnętrznych Tadeusza Mostowskiego

${ }^{4}$ J. Czołgoszewski, Więziennictwo Księstwa Warszawskiego, „Przegląd Więziennictwa Polskiego" 2010, nr 69, s. 138.

${ }^{5}$ A. Ossibach-Budzyński, Pawiak. Więzienie polityczne 1880-1915, Warszawa 2016, s. 45. 
dokonał rewizji jednego z warszawskich więzień śledczych, tzw. Prochowni ${ }^{6}$. Tragiczne warunki, jakie tam zastał, skłoniły go do zajęcia się problematyką tego rodzaju ośrodków penitencjarnych, jak również sytuacją osób tymczasowo aresztowanych ${ }^{7}$. Swoje spostrzeżenia i postulaty przedstawił w raporcie dla ministra sprawiedliwości, który to dokument stał się przyczynkiem do dyskusji nad reorganizacją więzień śledczych. W dokumencie tym autor wskazuje, jakie w jego ocenie warunki powinno spełniać każde więzienie inkwizycyjne:

a) zachować życie i zdrowie obwinionego, b) zasłonić go od zhańbienia, c) zapobiegać wszelkiemu moralnemu zepsuciu osadzonych, d) dopełniać tego wszystkiego, czego potrzeba do porządnego i prawnego biegu sprawiedliwości, tj. aby obwiniony odłączony od swoich wspólników i od innych winowajców dlatego, ażeby uniknąć wszelkiej zmowy i nauki o sposobie bronienia się w sądzie, aby czyniono różnicę między obwinionym pod sądowym badaniem będącym a wybadanym, zapadnięcia wyroku oczekującym, aby wybadany lub oczekujący wyroku tak długo tylko zostawał w więzieniu inkwizycyjnym, ile do ukończenia badania i do wydania wyroku potrzeba ${ }^{8}$.

Skarbek doszedł do wniosku, że warunkiem spełnienia powyższych założeń jest budowa nowego obiektu. Na skutek jego bezpośrednich starań, przy aprobacie Komisji Rządowej Sprawiedliwości, w 1835 r. został więc oddany do użytku nowy gmach położony u zbiegu ulic Pawiej i Dzielnej, jako pierwsze w Królestwie Polskim więzienie celkowe. Spełniało ono przynajmniej teoretycznie wszystkie warunki postulowane przez Skarbka, w myśl rodzącej się wówczas nowoczesnej nauki o więziennictwie9.

\section{INSTRUKCJA KOMISJI RZĄDOWEJ SPRAW WEWNĘTRZNYCH Z 26 LISTOPADA/8 GRUDNIA 1835 R.}

Władze rządowe doszły do wniosku, że ogólne przepisy instrukcji więziennej z 17 września 1823 r. będą niewystarczające do zakładanych nowoczesnych i humanitarnych zasad działalności nowego więzienia inkwizycyjnego w Warszawie:

[...] gdy dotychczasowe przepisy zarządu, porządku i karności więziennej, zawarte w ogólnej instrukcji, w dniu 17 września 1823 roku przez byłą Komisję

${ }^{6}$ F. Skarbek, Statystyka. Wyjątek z raportu Hr. Skarbka o więzieniach Królestwa w roku 1830, „Gazeta Sądowa Warszawska” 1832, nr 59, s. 504.

${ }^{7}$ Ibidem, s. 27.

${ }^{8}$ M. Senkowska, Raport Fryderyka Skarbka o warszawskim więzieniu śledczym z 1828 r, „Czasopismo Prawno-Historyczne” 1957, t. IX, z. 2, s. 261-263.

${ }^{9}$ E. Kaczyńska, Ludzie ukarani..., s. 346-347. 
Rządową Spraw Wewnętrznych i Policji wydanej, okazują się być niedostateczne w zastosowaniu swojem do zasad, podług których nowe więzienie inkwizycyjne wystawione zostało, Komisja Rządowa, uchylając takowe co do tegoż więzienia, po zniesieniu się z Kommissyą Rządową Sprawiedliwości w tej mierze, wydaje następujące, dla niego wyłącznie służyć mające urządzenia ${ }^{10}$.

Dla tego zakładu została więc wydana odrębna instrukcja z 26 listopada/ 8 grudnia 1835 r., która stała się podstawą organizacyjną Pawiaka. Od początku były jednak z jej wykonywaniem problemy. Wobec tego władze rządowe od lat 50. XIX w. dążyły do uchwalenia nowej instrukcji. W tym celu kilkakrotnie wzywały władze wojewódzkie do przekazania stosownych uwag co do oczekiwanych przez administrację więzienną zmian w dotychczasowych przepisach.

Jak czytamy w piśmie Komisji Rządowej Spraw Wewnętrznych i Duchownych z 20 maja/1 czerwca 1858 r. skierowanym do Rządu Gubernialnego Warszawskiego:

Gdy potrzeba tej Instrukcji okazuje się ze względu ciągłego w Domu Badań nieporządku i nieobeznania teraźniejszego zarządu więziennego z przepisami coraz więcej naglącą jest, a zmiany wskutek zaprowadzenia nowej organizacji sądownictwa wyniknąć mogące będą w niej swego czasu dopełnione - przeto Komisja Rządowa poleca Rządowi Gubernialnemu, aby rozporządzenia zwyż powołane jak najspieszniej wykona $c^{11}$.

W rezultacie propozycje zmian w dotychczasowych regulacjach zostały przedstawione przez Nadzorcę Głównego Więzienia Karnego w Warszawie w piśmie z 11/23 czerwca 1858 r. skierowanym do Rządu Gubernialnego Warszawskiego. Pozostaje pytanie, dlaczego pismo to nie pochodziło od Nadzorcy Głównego Więzienia Inkwizycyjnego. W zachowanym materiale źródłowym znalazło się rozporządzenie Komisji Rządowej Spraw Wewnętrznych i Duchownych zobowiązujące władze wojewódzkie do przedstawienia projektu nowej instrukcji, z którego wykonaniem były jednak trudności:

[...] ułożenie i przedstawienie Instrukcji dla tutejszego Domu Badań polecone zostało Rządowi Gubernialnemu przez reskrypt z 13/25 listopada 1855 r. Pomimo licznych zapewnień swoich i upływu znacznego czasu Rząd Gubernialny rozporządzenia tego dotąd nie dopełnił, chociaż tylko o porównanie dotychczasowej Instrukcji tego Zakładu w 1835 wydanej z ogólną Instrukcją więzienną z roku 1823 i przepisami następnie wydanymi ${ }^{12}$.

${ }^{10}$ Zbiór Przepisów Administracyjnych Królestwa Polskiego [dalej: ZPA], cz. VI: O aresztach $i$ więzieniach, t. I, Warszawa 1868, s. 390-391.

${ }^{11}$ Archiwum Główne Akt Dawnych [dalej: AGAD], zespół 227, Komisja Województwa Mazowieckiego/Rząd Gubernialny Warszawski, sygn. 10051.

12 Ibidem. 
Z dalszej korespondencji wynika, że władze wojewódzkie kilkakrotnie zwracały się do administracji warszawskiego więzienia inkwizycyjnego o przedstawienie stosownych uwag, co pozostawało jednak bez odpowiedzi. W związku z tym Rząd Gubernialny Warszawski, prawdopodobnie nie chcąc narażać się komisji rządowej, zlecił wykonanie tego zadania Nadzorcy Głównego Więzienia Karnego.

Ostatecznie nigdy nie wprowadzono nowej instrukcji dla Pawiaka. Z biegiem czasu uzupełniano tylko dotychczasową doraźnymi zarządzeniami wydawanymi przy rozwiązywaniu konkretnych spraw.

$\mathrm{Z}$ uwagi na zmiany w prawie karnym materialnym Komisja Rządowa Spraw Wewnętrznych i Duchownych zredagowała w 1859 r. nową ogólną instrukcję więzienną. Jak wskazuje Andrzej Ossibach-Budzyński, administracja więzienna Pawiaka posiłkowała się nowymi przepisami, gdy obowiązująca instrukcja z 1835 r. była niewystarczająca ${ }^{13}$.

\section{PRZEZNACZENIE NOWEGO WIĘZIENIA}

Nowe więzienie przeznaczone było zgodnie z art. 1 instrukcji ,wyłącznie dla osób o przestępstwa obwinionych, które z mocy decyzji sądowej z więzienia odpowiadać mają"14. Ponadto w więzieniu warszawskim trzymano „ubogich defraudantów”, którzy na mocy postanowienia Księcia Namiestnika z 10 lutego 1824 r. i decyzji Rady Administracyjnej z dnia 13 kwietnia 1832 r. podlegali władzy sądowo-administracyjnej ${ }^{15}$. Artykuł 2 instrukcji nakazywał, by w więzieniu warszawskim przebywali także „zbrodniarze na karę śmierci skazani, aż do spełnienia wyroku lub otrzymania ułaskawienia"16.

\section{BUDYNEK WIĘZIENNY}

Artykuł 13 instrukcji dzielił cały gmach więzienny na tzw. średni korpus dla sądownictwa i administracji oraz dwa trzypiętrowe skrzydła przeznaczone dla osadzonych ${ }^{17}$. Część sądową usytuowano od piwnicy po drugie piętro. W suterenie znajdowały się trzy lokale przeznaczone na depozyty sądowe. Na pierwszym piętrze były dwie sale posiedzeń sądowych, cztery izby dla kancelarii sądowej i podręcznego archiwum, zaś na drugim - 17 izb dla inkwirentów i podprokuratorów oraz dwie sale archiwalne i dla świadków (art. 14) ${ }^{18}$.

\footnotetext{
${ }^{13}$ A. Ossibach-Budzyński, Pawiak. Więzienie polityczne..., s. 60.

${ }_{14}$ ZPA, cz. VI, t. I, s. 391.

15 Ibidem.

16 Ibidem.

17 Ibidem, s. 395.

18 Ibidem, s. 395-396.
} 
Część administracyjną ulokowano w piwnicy i na parterze. I tak na samym dole (,w lokalu podziemnym”) zgodnie z art. 15 instrukcji „umieszczone będą wszelkie zakłady gospodarskie, jak to: kuchnie, spiżarnie, pralnie, suszarnie, kąpiele i składy, tudzież mieszkania dla strażników więziennych i ścisłe areszta dla więźni, za przestąpienie przepisów wewnętrznych ukaranych"19. Na parterze zaś znajdowało się mieszkanie nadzorcy, pisarza i odźwiernego, kancelaria więzienna, izba do przyjmowania i odwiedzania aresztantów, a także odwach (pomieszczenie dla żołnierzy pełniących wartę) oraz izba oficerska ${ }^{20}$. Pozostała część budynku miała być przeznaczona na cele więzienne.

Zasada przyświecająca całej organizacji pomieszczeń więziennych Pawiaka była wyrażona w art. 8 instrukcji:

Główna zasada zawiadywania więzieniem inkwizycyjnym jest ta, iż każdy obwiniony z mocy decyzji sądowej na ścisłem odosobnieniu trzymany, z żadnym innym współuwięzionym ani widywać, ani żadnych stosunków mieć nie powinien i że każdy z mocy decyzyi Sądu mniej ściśle osadzony, z tymi tylko współuwięzionymi widywać się i stosunki mieć może, którzy do jednego z nim oddziału należą i prócz tych żadnego innego więźnia znać nie powinien ${ }^{21}$.

Nadzorca Głównego Więzienia Karnego w Warszawie proponował w art. 8 instrukcji następujące zmiany:

[...] po wyrazach „i stosunki mieć” dodać należy „,w izbach wspólnych na tak zwaną wolną sekcję przeniesiony" - same zaś wyrazy powyższe ,i stosunki mieć” jako dwuznaczne wykreślić, w ich zaś miejsce użyć „w razie konieczności przy posługach lub spacerze mieć mają"22.

Dowodzi to, że najwyraźniej służba więzienna nie radziła sobie z porozumiewaniem się między sobą osadzonych, co z pewnością mogło mieć wpływ na prawidłowość postępowania karnego.

Dalej art. 16 instrukcji mówił:

[...] reszta całego gmachu, od wyliczonych dotąd lokalów należycie oddzielona, stanowi właściwe więzienie inkwizycyjne i to w ten sposób, iż piętro dolne nad podziemnem przeznaczone być ma w obydwóch skrzydłach na oddział ściśle odosobnionych, z tym wszakże zastrzeżeniem, iż gdyby dolne cele dla tamtych nie wystarczały, pewna ilość na jednej połowie pierwszego piętra na ten cel zajętą zostanie i na odwrót, że na dole mogą być mieszczeni mniej ściśle odosobnieni,

19 Ibidem, s. 397.

20 J. Czołgoszewski, Organizacja więziennictwa i służba więzienna w Królestwie Polskim w latach 1815-1868, „Przegląd Więziennictwa Polskiego” 2014, nr 85, s. 122.

21 ZPA, cz. VI, t. I, s. 393.

22 AGAD, zespół 227, sygn. 10051. 
gdyby ich liczba na pierwszym piętrze pomieścić się nie mogła. Całe drugie piętro w obydwóch skrzydłach przeznaczone jest więźni wybadanych i zapadnięcia wyroku oczekujących, niemniej skazanych na więzienie i odprowadzenia do miejsca kary oczekujących ${ }^{23}$.

\section{ARESZTANCI}

\subsection{Przyjmowanie do więzienia}

Do więzienia osadzonego przyjmował nadzorca na podstawie decyzji sądu (art. 24) ${ }^{24}$. Bezpośrednio przy wejściu każda osoba była rewidowana, myta i ubierana w strój więzienny:

[...] naprzód rozebrana i zrewidowana w osobnej do tego przeznaczonej izbie. Do rewizji kobiet użytą będzie kobieta do dozoru onychże przeznaczona, następnie zaprowadzony zostanie aresztowany do łazienki, celem umycia się, poczem dostanie ubiór instytutowy, jeśli własnego, stosownie do rozporządzeń poniżej umieszczonych, nie ma. Będąc przybrany zaprowadzony zostanie do kancelarii więziennej, zapisania go w księgi rodowodowej, do kontroli i odczytania mu wewnętrznych urządzeń, do których przez cały czas pobytu swego stosować się powinien ${ }^{25}$.

Ciekawą uwagę zgłosił Nadzorca Głównego Więzienia Karnego w Warszawie:

[...] w art. 25 wyjaśnić wyrazy „do rewizji kobiet będzie użyta kobieta do dozoru onych przeznaczona", gdyż jak wiadomo etat dozorczyni kobiet w domu badań nie istnieje ${ }^{26}$.

Dalej art. 26 nakazuje:

[...] rzeczy, które więzień z sobą przyniesie, mają być zapisane do osobnej księgi sznurowej i albo złożone we właściwym składzie, jeżeli otrzyma odzież skarbową albo oddane jemu samemu do użycia, lecz tylko w ilości do jednego ubrania potrzebnej. Wykaz tych rzeczy z księgi sznurowej wycięty, każdemu aresztowanemu oddany zostanie ${ }^{27}$.

Problem polegał na tym, że aresztant nie mógł mieć przy sobie żadnych dokumentów. Tak też Nadzorca Głównego Więzienia Karnego zwrócił uwagę na konieczność wyjaśnienia tej kwestii:

\footnotetext{
${ }^{23}$ ZPA, cz. VI, t. I. s. 398-400.

${ }^{24}$ Ibidem. s. 403.

25 Ibidem.

${ }^{26}$ AGAD, zespół 227, sygn. 10051.

${ }^{27}$ ZPA, cz. VI, t. I, s. 405.
} 
[...] w art. 26 wyjaśnić wyrazy „wykaz tych rzeczy z księgi sznurowej wycięty, każdemu aresztantowi oddany zostanie", gdyż aresztant żadnego papieru przy sobie mieć nie może i dotąd takie wycinanie kwitów jako niemożliwe nie praktykowało $\operatorname{się}^{28}$.

\subsection{Klasyfikacja osadzonych}

Omawiana instrukcja wprowadzała nieznaną dotychczas klasyfikację. Więźniowie zostali bowiem podzieleni na trzy główne oddziały: pierwszy - dla obwinionych będących pod badaniem sądowym, drugi - dla osób, względem których postępowanie zostało zakończone, a tylko oczekujących na wyrok, trzeci - dla skazanych na karę śmierci (art. 28) ${ }^{29}$.

Dodatkowo oddział dla osób pod badaniem będących dzielił się na dwie sekcje: ściśle odosobnionych oraz pojedynczo zamkniętych bez ścisłego odosobnienia. Dla każdej z tych sekcji przeznaczone były pojedyncze cele (art. 29) ${ }^{30}$.

Każdy nowo wchodzący aresztant trafiał do oddziału pierwszego. O sekcji decydował sąd kierujący w zależności od wagi popełnionego czynu. Cele w sekcji pierwszej miały być zamknięte całą dobę, osadzeni mieli zaś być pozbawieni jakiejkolwiek komunikacji z innymi współwięźniami, a także ze światem zewnętrznym. Jedynie za zezwoleniem sądu mogli mieć kontakt z lekarzem i kapelanem (art. 32) (31 $^{\text {. }}$

W sekcji drugiej oddziału pierwszego obowiązywały nieco mniejsze obostrzenia. Tutaj więźniowie mogli w określonych godzinach widywać się z innymi osadzonymi, choć mieli pozostawać w odosobnieniu. Mogli oni żądać odwiedzin kapelana lub lekarza więziennego (w razie cięższej choroby byli umieszczani w lazarecie więziennym) bądź obrońcy. Za zgodą sądu mieli też prawo do odwiedzin osób postronnych (art. 34) ${ }^{32}$. W tym przypadku także Nadzorca Głównego Więzienia Karnego wskazał na wątpliwości:

[...] z jednej strony w oddziale I sekcji 2 (tj. na pierwszym piętrze) mieszczeni są ważni i niewybadani więźnie, a tem samem widywanie się ich z sobą lub z innymi najgorsze dla biegu spraw robiłoby następstwa, tak też i spacery po korytarzach więziennych miejsca mieć nie mogą i dotąd nie praktykowały się.

Nadzorca zwrócił też uwagę na konieczność wskazania, jaka to jest sekcja druga:

[...] wyraźnie trzeba odróżnić, jaka to jest sekcja 2-ga, gdyż ja rozumiem tylko sekcję 1-wszą ścisłą z oddziałami 1, 2, 3 i 4 złożoną i sekcję 2-gą zwaną wolną, czyli

\footnotetext{
${ }^{28}$ AGAD, zespół 227, sygn. 10051.

${ }^{29}$ ZPA, cz. VI, t. I, s. 405.

${ }^{30}$ Ibidem.

31 Ibidem, s. 407.

32 Ibidem, s. 409.
} 
z izbami wspólnymi. W instrukcji zaś za ścisłą sekcję uważany jest tylko oddział 1-wszy i 2-gi, co na szkodliwe pomyłki bieg i porządek służbowy narażać może ${ }^{33}$.

Osadzeni w pierwszym oddziale mogli ,zatrudniać robotami w własnych celach, z zastrzeżeniem, aby narzędzi ostrych lub niebezpiecznych przedmiotów nie używali" (art. 37) ${ }^{34}$. Ponadto aresztanci z sekcji drugiej za zezwoleniem sądu mogli być używani do posług wewnętrznych ${ }^{35}$.

Oddział drugi przeznaczony był dla osób oczekujących wydania wyroku lub przeniesienia do miejsca odbycia kary, jak również dla defraudantów pozostających w dyspozycji organów administracyjnych (art. 39) ${ }^{36}$. W tym oddziale więźniowie byli lokowani zgodnie z art. 40 instrukcji według określonej klasyfikacji:

a) kobiety bez różnicy razem w jednej Sali, gdyby ich było mało, a w dwóch oddzielając, b) chłopcy małoletni do lat 20-tu z wyłączeniem tych, którzy już poprzednio byli w więzieniu, c) przestępcy pełnoletni z Warszawy i innych miast, rozróżniani na pierwszy raz uwięzionych i na takich, co za powtarzanie przewinienia są zatrzymani, d) przestępcy z wsiów podobnież rozróżnieni i oddzieleni w salach, jeśli lokalność i liczba ich na to pozwala, e) żydzi, oddzieleni na raz uwięzionych i na powracających, f) defraudanci wszyscy razem z tem zastrzeżeniem, aby do jednej sprawy wpływający łączeni nie byli, tak w salach, jak i na przechodzie ${ }^{37}$.

W oddziale trzecim, jak już wskazano, przebywały wyłącznie osoby oczekujące na wykonanie kary śmierci.

\section{PRAWA I OBOWIĄZKI OSADZONYCH}

\subsection{Prawo utrzymania}

Przebywający w Głównym Więzieniu Inkwizycyjnym w Warszawie mieli ze strony państwa zapewnione utrzymanie. Przy czym jak stanowił art. 46 instrukcji:

[...] więźniowie kosztem skarbowym utrzymywani, poprzestać winni na żywności, odzieży i posłaniu, jakie im w instytucie, stosownie do ogólnych przepisów, dostarczone będą i nie mają prawa żądać więcej wygód lub przedmiotów jakich bądź nad to, co dla nich jest przepisane ${ }^{38}$.

\footnotetext{
${ }^{33}$ AGAD, zespół 227, sygn. 10051.

${ }^{34}$ Ibidem.

${ }^{35}$ ZPA, cz. VI, t. I, s. 411.

36 Ibidem.

37 Ibidem, s. 411-413.

${ }^{38}$ Ibidem, s. 415.
} 
Aresztanci mogli otrzymywać lepsze wyżywienie, wpłacając odpowiednią sumę do kasy więzienia (art. 47) 39 $^{39}$ mieli możliwość posiadania własnej odzieży, obuwia, pościeli (art. 48) ${ }^{40}$, mogło być im też za zgodą sądu w porze zimowej dostarczane światło (art. 49) ${ }^{41}$, co jednak nie było praktykowane i Nadzorca Głównego Więzienia Karnego w swoich uwagach postuluje o jego wykreślenie ${ }^{42}$.

\subsection{Prawo widzeń}

Prawo widzeń przysługiwało osadzonym tylko za zgodą sądu. Widzenia odbywały się w obecności osoby delegowanej przez sąd i strażnika więziennego w specjalnie do tego przeznaczonym pomieszczeniu, gdzie aresztant oddzielony był kratą od odwiedzającego. Instrukcja regulowała także maksymalny czas odwiedzin, który nie mógł przekroczyć 15 minut (art. 51) ${ }^{43}$.

Aby zapobiec przynoszeniu osadzonym niedozwolonych przedmiotów, odwiedzający podlegali rewizji:

[...] osoba odwiedzająca powinna się poddać rewizyi przy wejściu swojem do izby wizytowej, czyli jakich zakazanych przedmiotów z sobą nie przynosi. Wszelkie zaś przedmioty do ubioru jej nie należące, w kancllaryi, przy izbie odwiedzin zostawić powinna (art. 52) ${ }^{44}$.

Instrukcja narzucała ponadto osobie odwiedzającej określony sposób zachowania w podczas wizyty:

[...] podczas odwiedzin obowiązana jest mówić głośno i nie innym językiem jak polskim, a w razie gdyby tego języka nie umiała, powinien być obecny przy jej odwiedzeniu urzędnik lub officyalista, właściwy jej język rozumiejący. Pod żadnym pozorem mig i tajnych znaków odwiedzającym używać, ani w sprawie obwinionego mówić nie wolno (art. 52) ${ }^{45}$.

\subsection{Obowiązki}

Jak stanowił art. 56 instrukcji:

[...] obwiniony, do więzienia inkwizycyjnego odesłany, winien jest bezwarunkową uległość przepisom i urządzeniom tego instytutu, zwierzchnikom swoim, tak nadzorcy, jako i wszystkim innym osobom do administracji więziennej należącym ${ }^{46}$.

\footnotetext{
39 Ibidem, s. 417.

40 Ibidem.

41 Ibidem.

42 AGAD, zespół 227, sygn. 10051.

43 Ibidem.

44 Ibidem, s. 419.

45 Ibidem.

46 Ibidem, s. 423.
} 
Jednym z podstawowych obowiązków było informowanie służby więziennej w razie powzięcia informacji o planowanej przez osadzonych ucieczce (art. 58) ${ }^{47}$.

Dalej w art. 59 instrukcji czytamy:

[...] każdy aresztowany, czy na osobności, czy też wspólnie z innymi osadzony, powinien się zachowywać spokojnie, nie robić żadnych hałasów, nie krzyczeć, nie stukać, nie śpiewać, nie używać słów zelżywych, ani się kłócić z osobami służby lub współuwięzionemi, nie namawiać nikogo do złego, ani im złym przewodniczyć przykładem ${ }^{48}$.

Ponadto aresztanci byli zobowiązani do zachowania higieny osobistej, jak również czystości i porządku w celach (art. 60) ${ }^{49}$. Nie mogli posiadać przy sobie ostrych narzędzi ani rozmawiać przez okno celi z osobami z zewnątrz (art. 62 i 63$)^{50}$. Za naruszenie powyższych reguł art. 64 instrukcji przewidywał kary dyscyplinarne: „napomnienie, odjęcie objadu, areszt ścisły w celi suterynowej, przykucie na łańcuchu w celi samotnej, kara cielesna”. Kary te wymierzała administracja więzienna, gdy chodziło o drobniejsze przewinienia, zaś w sprawach poważniejszych orzekał sąd $\mathrm{d}^{51}$.

W związku z wprowadzeniem od 1848 r. Kodeksu Kar Głównych i Poprawczych Rada Administracyjna uznała za konieczne wprowadzenie nowych przepisów dotyczących karności więźniów, wydając 23 czerwca/5 lipca 1853 r. tzw. Przepisy o karności domowej więźni.

Jak pisze Nadzorca Głównego Inkwizycyjnego w Warszawie:

[cały] tytuł IV tj. „Obowiązki i karność więźni” instrukcji z 1835 r. zastępują „Przepisy o karności domowej więźni” przez Radę Administracyjną na dniu 23 czerwca/5 lipca 1853 r. potwierdzone i dlatego artykuły 56, 57, 58, 59, 60, 61, 62, $63,64,65,66$ usunięte być mają ${ }^{52}$.

Nie wiadomo, czy należy to traktować jedynie jako postulat autora, czy też w jego ocenie moc obowiązująca tych przepisów została rozciągnięta na Główne Więzienie Inkwizycyjne w Warszawie. Niestety z wydanego przez Radę Administracyjną reskryptu z 23 czerwca/5 lipca 1853 r. nie wynika, czy nowe regulacje mają mieć również zastosowanie do Głównego Domu Badań w Warszawie. Wydaje się jednak, że gdyby organ rządowy chciał, aby obowiązywały one w tej jednostce, wyraziłby to wprost.

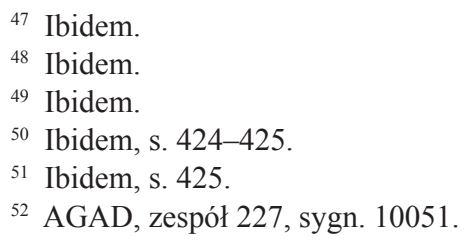




\section{SŁUŻBA WIĘZIENNA}

Omawiana instrukcja dzieliła służbę więzienną na trzy kategorie: administracyjno-ekonomiczną, duchowną i lekarską (art. 67) ${ }^{53}$. Służbę duchowną stanowił kapelan więzienia i jeden ze strażników pełniący posługę kościelną. W skład trzeciej grupy wchodzili zaś lekarz i chirurg.

\subsection{Służba administracyjno-ekonomiczna}

Do pierwszej kategorii należeli: nadzorca, pisarz, starszy strażnik, jedenastu strażników i odźwierny. Na czele więzienia inkwizycyjnego w Warszawie stał nadzorca. Pełnił on nadzór nad całą służbą administracyjno-ekonomiczną i osobiście odpowiadał za uchybienia swoich podwładnych w wykonywaniu obowiązków służbowych (art. 68) ${ }^{54}$. Miał więc prawo przedstawiać kandydatury na wakujące miejsca na stanowisko strażnika, jak również mógł się domagać dymisji danej osoby, jeżeli źle wypełniała swoje obowiązki służbowe (art. 71) ${ }^{55}$.

Nadzorca nie mógł bez zezwolenia władzy zwierzchniej opuszczać więzienia na dłużej niż jeden dzień (w takim przypadku zastępował go pisarz $)^{56}$. Tutaj Nadzorca Głównego Więzienia Karnego w Warszawie w swoich uwagach postulował, by doprecyzować ten przepis, tak by obwiązek powrotu do więzienia do godz. 19.00 dotyczył także nadzorcy więzienia:

[...] w art. 68 możność wydalenia się Nadzorcy poza obręb murów więziennych, jak również możność oddalania w tem ograniczyć go godziny 7-mej wieczorem, to jest tak ażeby tak Nadzorca jak i każdy inny officyalista był obecnym przy raportach wieczornych, o tey godzinie odbywanych ${ }^{57}$.

Zgodnie z art. 70 instrukcji w ramach swoich czynności nadzorca był zobowiązany do stałych kontroli więzienia z zakresie czystości, porządku i przestrzegania przepisów dotyczących wewnętrznej organizacji instytutu, za co ponosił odpowiedzialność:

${ }^{53}$ ZPA, cz. VI, t. I, s. 427.

${ }^{54}$ Ibidem.

55 Ibidem, s. 429.

${ }^{56}$ Art. 69: „Żaden z officyalistów i sług więziennych nie może się oddalać po za mury więzienia bez wyraźnego na to pozwolenia Nadzorcy, który nie ma prawa udzielać podobnego pozwolenia na dłużej jak na dzień jeden, to jest od siódmej z rana, do dziewiątej wieczorem. Jeżeli się sam oddala z więzienia, co także na nie dłużej, jak na dzień jeden, bez pozwolenia zwierzchniej władzy, nastąpić może, wówczas winien uprzedzić o tem Pisarza i zalecić mu, aby go w nadzorze zastąpił. Nigdy z więzienia Nadzorca i Pisarz razem oddalać się nie powinni”.

${ }^{57}$ AGAD, zespół 227, sygn. 10051. 
[...] nadzorca obowiązany odbywać rewizje więzienne tak, aby przynajmniej jedną sekcyę lub oddział zrewidował. Prócz tego nie przepisuje się, ani czasu, ani kolei, w jakich różne oddziały i lokale więzienne ma zwiedzać, lecz stanowi się, za wszelką nieczystość, wszelki nieporządek, wszelkie niedopełnienie przepisów, jako i przypadki ucieczki lub wyłomu więźni, na niego głównie odpowiedzialność ściągają i że się w żadnym przypadku niedbalstwem lub uchybieniem podwładnych składać nie może $\mathrm{e}^{58}$.

Ponadto nadzorca odpowiadał za dostarczenie odpowiedniej ilości zdrowej żywności (art. 73) ${ }^{59}$.

Co ważne, przepisy instrukcji nakładały na nadzorcę obowiązek odpowiedniego zachowania w stosunku do osadzonych:

[...] bez żadnego pobłażania, ani sprzyjania jednemu więcej jak drugiemu, winien się Nadzorca obchodzić ze wszystkimi więźniami łagodnie i względnie, o tyle, o ile wypełniają wszystko co niniejszym urządzeniem jest względem nich przepisanem. Wystrzegać się powinien wszelkich uniesień i gwałtowności, jako i używania wyrazów obelżywych, nawet $\mathrm{i}$ wtenczas gdy kary na przekraczających wymierzać będzie $(\text { art. } 74)^{60}$.

Drugą osobą należącą do służby administracyjno-ekonomicznej był pisarz ${ }^{61}$. Jego zadaniem było prowadzenie korespondencji i ksiąg przyjęć i zwolnień aresztantów, czuwanie nad rozliczeniami finansowymi, pomaganie nadzorcy w nadzorze nad więzieniem oraz zastępowanie go w czasie nieobecności (art. 75) ${ }^{62}$.

Istotną funkcję pełnił także starszy strażnik. Dbał o dostarczenie odpowiednich ubiorów, dozór nad kuchnią, a także

[...] przestrzeganie spokojności, porządku i czystości w tej części gmachu więziennego, która nie zostaje pod bezpośrednim dozorem oddzielnych strażników, tudzież na dziedzińcu spacerowym i w podwórzach gospodarskich [oraz] pilnowanie całości i dobrego utrzymania wszelkich sprzętów, naczyń i utensyliow więziennych; prócz tego winien czuwać wraz z innymi officyalistami nad bezpieczeństwem i porządkiem całego zakładu (art. 76) ${ }^{63}$.

Z kolei rolą strażników było przede wszystkim zapewnienie bezpieczeństwa i porządku. Do ich obowiązków należało czuwanie nad odpowiednim zachowaniem osadzonych, a o wszelkich uchybieniach musieli informować nadzorcę. Sami zasadniczo nie mogli używać siły fizycznej:

\footnotetext{
${ }^{58}$ ZPA, cz. VI, t. I, s. 431.

${ }^{59}$ Ibidem.

${ }^{60}$ Ibidem.

${ }^{61}$ J. Czołgoszewski, Organizacja.., s. 123.

${ }^{62}$ ZPA, cz. VI, t. I, s. 431.

${ }^{63}$ Ibidem, s. 433.
} 
[...] nie wolno jest strażnikowi używać obelżywych wyrazów względem więźni, a tem mniej cieleśnie ich karać wyjąwszy jedynie przypadki porwania się więźnia na niego, w którym to razie mocen jest odeprzeć siłą napaść gwałtowną i użyć nawet broni jaką nosi w obronie swojej (art. 77) ${ }^{64}$.

Nie wolno też im było rozmawiać z więźniami, przyjmować od nich czegokolwiek ani udzielać pożyczek (art. 78) ${ }^{65}$. Za niedopełnienie powyższych obowiązków ponosili odpowiedzialność dyscyplinarną w postaci obniżenia pensji, degradacji służbowej, a nawet wydalenia z pracy (art. 78) ${ }^{66}$.

W tym zakresie Nadzorca Głównego Więzienia Karnego w Warszawie wskazał, iż przepisy instrukcji dla Głównego Więzienia Inkwizycyjnego w Warszawie z 26 listopada/8 grudnia 1835 r. dotyczące strażników należy uchylić, ponieważ zostały one zastąpione przepisami wydanymi przez Komisję Rządową Spraw Wewnętrznych i Duchownych z 4/16 marca 1853 r. - tzw. Instrukcję dla strażników. Podobnie jak w przypadku Przepisów o karności domowej więźni z 23 czerwca/ 5 lipca 1853 r., sam akt nie wskazywał, czy przepisy te uchylają omówione regulacje instrukcji z $1835 \mathrm{r}$.

Zadaniem odźwiernego było natomiast czuwanie nad prawidłowością wejść i wyjść z więzienia.

[...] pilnować będzie tego odźwierny, ażeby osoby do Sądu należące lub obce, do tegoż Sądu powołane, wchodziły prosto schodami na górę i nie udawały się, ani na dół do sutenerów, ani do żadnego z dwóch bocznych korytarzy. Nowo przyprowadzonego aresztanta, jako i każdą osobę obcą przybywającą, wyjąwszy do sądu powołaną obowiązany jest odźwierny odprowadzać do kancellaryi więziennej ${ }^{67}$.

\subsection{Służba lekarska}

Lekarz miał obowiązek przebywać w więzieniu codziennie w godzinach przedpołudniowych, choć nie było w tym względzie szczegółowych regulacji.

[Jednak] w każdym przypadku niebezpiecznej choroby jednego lub kilku więźni, winien jest lekarz więzienny drugą wizytę odbyć w więzieniu w godzinach popołudniowych. Obowiązanym jest także przybyć do niego na każde wezwanie Nadzorcy, w przypadkach nagłego ratunku wymagających ${ }^{68}$.

\footnotetext{
${ }^{64}$ Ibidem, s. 434-435.

${ }^{65}$ Ibidem, s. 435.

${ }^{66}$ Ibidem.

67 Ibidem, s. 437.

${ }^{68}$ Ibidem, s. 440.
} 
W pierwszej kolejności wizytował on szpital więzienny i wydawał zalecenia dotyczące dalszego leczenia przebywających tam pacjentów, a następnie przyjmował nowo zgłaszających się chorych (art. 92) ${ }^{69}$.

Chirurg więzienny był zaś pomocnikiem lekarza, a jego obowiązkiem było wykonywanie poleceń lekarza i pilnowanie, by były przestrzegane wszelkie zalecenia lekarskie co do sposobu leczenia i diety. Dbał on o czystość i porządek w salach szpitalnych. Zgodnie z przepisami instrukcji miał obowiązek co najmniej dwa razy dziennie odwiedzać lazaret więzienny (art. 93) ${ }^{70}$.

\subsection{Służba boża}

Posługa duchowa $\mathrm{w}$ więzieniu należała do kapelana, który odprawiał msze w kaplicy więziennej, udzielał nauk religijnych, odwiedzał w celach aresztantów przebywających w odosobnieniu, a także udzielał ostatniego namaszczenia:

Kapelan więzienia inkwizycyjnego obowiązany jest: a) odbywać nabożeństwo i udzielać nauki religijne tym z pomiędzy aresztowanych, którzy razem mszy słuchać mogą, słuchać wszystkich spowiedzi; b) odwiedzać w celach aresztantów ściśle osadzonych, aby wzbudzić w nich żal i pokorę i nieść im pociechy religijne, c) udzielać ostatniego sakramentu konającym (art. 94) ${ }^{71}$.

Odprawianie nabożeństw odbywało się na korytarzach więziennych i dlatego kapelan posiadał przenośny ołtarz. Z okazji ważniejszych świąt kapelan dobierał do pomocy innych księży, tak by nabożeństwa mogły odbywać się jednocześnie na kilku oddziałach. Miał również prawo wyznaczyć jednego z więźniów do codziennego głośnego odmawiania modlitwy ${ }^{72}$. Nadzorca wskazał, iż

[...] w art. 94 z uwagi, że dziś istnieje Kaplica stała, może wypadałoby coś zmienić stosownie do miejscowości. W tymże artykule odmawianie z innymi więźniami przez jednego z uwięzionych pacierzy zastosować się nie da i dotąd nie jest praktykowanem ${ }^{73}$.

Kapelan miał także prawo wybrania ,sobie jednego ze strażników do posługi kościelnej” (art. 67). W tym przedmiocie Nadzorca Głównego Więzienia Karnego twierdził:

\footnotetext{
69 Ibidem, s. 447.

70 Ibidem, s. 449.

71 Ibidem, s. 452.

72 J. Czołgoszewski, Organizacja..., s. 123.

73 AGAD, zespół 227, sygn. 10051.
} 
[...] z art. 67 wyjaśnić wyrazy „z wolnością wybrania sobie jednego ze Strażników do posługi kościelnej” gdyż naznaczanie pozycji i wybór służby dla każdego strażnika należy jedynie do nadzorcy ${ }^{74}$.

\section{NADZÓR}

Nadzór zwierzchni nad omawianym więzieniem inkwizycyjnym pełniła Rada Opiekuńcza Więzień Warszawskich (art. 96) ${ }^{75}$. Zadaniem jej było czuwanie nad przestrzeganiem przepisów przedmiotowej instrukcji, korygowanie dostrzeżonych uchybień i informowanie o nich władzy zwierzchniej. W tym celu co najmniej raz w miesiącu dwóch delegowanych urzędników miało przeprowadzać w instytucie kontrolę. W razie potrzeby każdy z członków Rady Opiekuńczej mógł także w każdej chwili przeprowadzić dodatkową rewizję instytutu (art. 97) ${ }^{76}$.

Nadzorca Głównego Więzienia w Warszawie w swoich postulatach podnosił, iż art. 96 i 97 instrukcji należy usunąć i w tym zakresie stosować przepisy obowiązującej instrukcji więziennej z 17 września 1823 r., w której nadzór więzień powierzono władzom administracyjnym (komisarzom wojewódzkim lub komisarzom powiatowym) i właściwym sądom. Autor nie podaje jednak uzasadnienia swoich postulatów, choć wydają się one zasadne, brakowało chyba racjonalnego powodu, by nadzór nad tą jednostką powierzyć Radzie Opiekuńczej.

W zakresie kwestii finansowych kontrolę sprawowała Komisja Województwa Mazowieckiego (art. 99) ${ }^{77}$.

\section{PODSUMOWANIE}

Przedstawiona instrukcja dla Głównego Więzienia Inkwizycyjnego w Warszawie była aktem prawnym, który wprowadził wiele nowych rozwiązań mających na celu organizację działalności tego obiektu na zasadach więzienia celkowego. $\mathrm{Na}$ uwagę zasługują tu przepisy instrukcji ściśle rozdzielające pomieszczenia instytutu na część zajmowaną przez korpus sądowo-administracyjny i skrzydła przeznaczone wyłącznie dla osadzonych, gdzie zorganizowano 120 cel pojedynczych i 20 wspólnych.

Ważne były także szczegółowe przepisy dotyczące klasyfikacji osadzonych (czego nie było w ogólnych przepisach instrukcji więziennej z 1823 r.) z uwagi na płeć, wiek, wagę popełnionego przestępstwa, etap postępowania sądowego, kwestię powrotu do przestępstwa, a nawet pochodzenie.

\footnotetext{
${ }^{74}$ Ibidem.

${ }^{75}$ ZPA, cz. VI, t. I, s. 449.

${ }^{76}$ Ibidem, s. 454.

77 Ibidem, s. 455.
} 
Oddany do użytku nowoczesny obiekt więzienny wymagał nowej organizacji całej administracji wewnętrznej, którą podzielono na trzy piony: administracyjno-ekonomiczny, duchowy i lekarski, precyzyjnie określając uprawnienia i obowiązki wszystkich funkcjonariuszy.

Powyższą instrukcję należy ocenić pozytywnie na tle dotychczasowych ogólnych przepisów więziennych, choć - jak wynika chociażby z uwag wniesionych przez Nadzorcę Głównego Więzienia Karnego w Warszawie - były pewne problemy z jej wykonywaniem, związane np. $\mathrm{z}$ brakiem etatów więziennych dla kobiet czy zapobieganiem porozumiewaniu się między osadzonymi.

Podane przykłady są jedynie niewielkim wycinkiem całego obrazu. Potrzebna jest analiza szerszego materiału archiwalnego ukazującego funkcjonowanie w praktyce tych przepisów. Niestety poszukiwanie tych dokumentów jest bardzo trudne, a zachowane źródła pochodzą już głównie z XX w.

Zupełnie inną kwestią było stosowanie przez władze administracyjne Głównego Domu Badań w Warszawie przepisów o karności domowej więźni z 23 czerwca/ 5lipca 1853 r. czy instrukcji dla strażników z 4/16 marca 1853 r. Czy przepisy te faktycznie były stosowane przez administrację więzienną, trudno jednoznacznie odpowiedzieć. Być może posiłkowano się tymi regulacjami i stąd postulat Nadzorcy Głównego Domu Kary, by regulacje te obowiązywały zamiast dotychczasowych zawartych w instrukcji z $1835 \mathrm{r}$.

\section{THE ORDER FOR THE MAIN INQUISITORIAL PRISON IN WARSAW OF THE $26^{\mathrm{TH}}$ OF NOVEMBER $/ 8^{\mathrm{TH}}$ OF DECEMBER 1835 AND THE COMMENTS TO IT OF THE SUPERVISOR OF THE MAIN PENAL PRISON IN WARSAW OF THE $11^{\mathrm{TH} / 23^{\mathrm{RD}}}$ OF JUNE 1858}

\section{Abstract}

Being remanded in custody is a preventive measure which was already known in the Polish law of old. However, during the entire period of the existence of the Polish-Lithuanian Commonwealth, there was no regulation concerning the grounds for applying this measure, authorized entities or the admissible term of detention without a sentence of the court. Similarly, it was exceedingly rare to encounter separate places designated for temporarily holding people in custody. First concepts of principles concerning the execution of provisional detention only appeared in the second half of the $18^{\text {th }}$ century. The final period of the Kingdom of Poland brought about practical reforms in the organization of the prison system also including reforms in the field of execution of pre-trial detention. Polish penitentiary scientists, who were under the influence of the European trends of the Age of Enlightenment, had a quite significant input in this field. One of them was Fryderyk Skarbek and thanks to him a modern detention centre, called Pawiak, which was designed to hold detainees during the investigation, was opened in Warsaw in 1835. The article pre- 
sents the rules and regulations concerning the functioning of the Main Inquisitorial Prison which were based on the order issued on $26^{\text {th }}$ of November $/ 8^{\text {th }}$ of December 1835 as well as on the comments to it which can be found in a document of the $11^{\text {th }} / 23^{\text {rd }}$ of June 1858 in “Archiwum Główne Akt Dawnych" [The Central Archives of Historical Records].

Keyw ord s: Kingdom of Poland, prison system, remand, penitentiary science, history of law, penal enforcement code 